\title{
Prevalence and associated predictors of HIV and syphilis among women, south of
}

\author{
Brazil \\ Prevalência e preditores associados ao HIV e sífilis entre mulheres, do sul do Brasil \\ Prevalencia y predictores asociados del VIH y la sífilis en mujeres del sur de Brasil
}

Received: 09/23/2021 | Reviewed: 09/30/2021 | Accept: 10/04/2021| Published: 10/09/2021

\author{
Natália de Carvalho Scharf Santana \\ ORCID: https://orcid.org/0000-0002-3823-1977 \\ State University of Maringa, Brazil \\ E-mail: nataliascharf@hotmail.com \\ Camila Barros Galinari \\ ORCID: https://orcid.org/0000-0001-9728-8298 \\ State University of Maringa, Brazil \\ E-mail: camissgalinari@gmail.com \\ Izabel Galhardo Demarchi \\ ORCID: https://orcid.org/0000-0001-5764-9511 \\ State University of Maringa, Brazil \\ E-mail: bel_galhardo@yahoo.com.br \\ Marcia Edilaine Lopes Consolaro \\ ORCID: https://orcid.org/0000-0001-9102-4865 \\ State University of Maringa, Brazil \\ E-mail: melconsolaro@ gmail.com \\ Jorge Juarez Vieira Teixeira \\ ORCID: https://orcid.org/0000-0001-7719-5350 \\ State University of Maringa, Brazil \\ E-mail: jjvteixeira@gmail.com
}

\begin{abstract}
To investigate the general prevalence of sexually transmitted infections (STIs) and the factors associated with syphilis and HIV in women treated in the Integrated Health System (SINAS). Cross-sectional database study with 6.993 patients treated at a referral center in the state of Paraná, Brazil, from January 2013 to December 2015. The overall prevalence was $2.39 \%$ for syphilis and HIV, being 0.65 and $0.22 \%$ for pregnant women and 3.07 and $0.78 \%$ for non-pregnant women, respectively. After adjusting the variables in the logistic regression model, the main predictors associated with syphilis were the age groups 41 to 59 and 60 to 83 years old (p <0.001), non-pregnant women ( $\mathrm{p}<0.01)$, marital status married ( $\mathrm{p}<0.001)$, drug use $(\mathrm{p}<0.01)$ and previous STIs $(<0.001)$. For HIV, the predictors were city of residence $(<0.001)$, reason for search $(\mathrm{p}<0.01)$, reported previous STTs $(\mathrm{p}<0.001)$. The population served had a higher prevalence of syphilis when compared to the international panorama, while the HIV values were lower. The predictors associated with STIs were non-pregnant, heterosexual women, aged between the second and fourth decade of life, higher education and who did not use condoms regularly. This study presents relevant information for the evaluation and development of measures that prevent, control and are related to the diagnosis and treatment of the investigated STIs.
\end{abstract}

Keywords: Epidemiology; Prevalence; Risk factors; Sexually transmitted infections.

\section{Resumo}

Investigar a prevalência geral de infecções sexualmente transmissíveis (ISTs) e os fatores associados à sífilis e ao HIV em mulheres atendidas no Sistema Integrado de Saúde (SINAS). Estudo de banco de dados transversal com 6.993 pacientes atendidos em um centro de referência no estado do Paraná, Brasil, de janeiro de 2013 a dezembro de 2015. A prevalência geral foi de 2,39\% para sífilis e HIV, sendo 0,65 e $0,22 \%$ para gestantes e 3,07 e $0,78 \%$ para mulheres não grávidas, respectivamente. Após o ajuste das variáveis no modelo de regressão logística, os principais preditores associados à sífilis foram as faixas etárias de 41 a 59 e 60 a 83 anos (p <0,001), mulheres não grávidas (p $<0,01$ ), estado civil casado ( $\mathrm{p}<0,001)$, uso de drogas ( $\mathrm{p}<0,01)$ e DST anterior $(<0,001)$. Para o HIV, os preditores foram cidade de residência $(<0,001)$, motivo da busca $(\mathrm{p}<0,01)$, relatou DST prévia $(\mathrm{p}<0,001)$. A população atendida apresentou maior prevalência de sífilis quando comparada ao panorama internacional, enquanto os valores 
do HIV foram menores. Os preditores associados às IST foram mulheres heterossexuais não grávidas, com idade entre a segunda e a quarta década de vida, ensino superior e que não usavam preservativos regularmente. Este estudo apresenta informações relevantes para a avaliação e desenvolvimento de medidas que previnam, controlam e estão relacionadas ao diagnóstico e tratamento das IST investigadas.

Palavras-chave: Epidemiologia; Prevalência; Fatores de risco; Infecções sexualmente transmissíveis.

\section{Resumen}

Investigar la prevalencia general de infecciones de transmisión sexual (ITS) y los factores asociados a la sífilis y al VIH en mujeres atendidas en el Sistema Integrado de Salud (SINAS). Estudio de base de datos transversal con 6.993 pacientes tratados en un centro de referencia en el estado de Paraná, Brasil, desde enero de 2013 hasta diciembre de 2015. La prevalencia global fue de $2,39 \%$ para la sífilis y el VIH, siendo de 0,65 y $0,22 \%$ para las mujeres embarazadas y de 3,07 y 0,78\% para las no embarazadas, respectivamente. Tras ajustar las variables en el modelo de regresión logística, los principales predictores asociados a la sífilis fueron los grupos de edad de 41 a 59 y de 60 a 83 años ( $p<0,001$ ), las mujeres no embarazadas ( $p<0,01$ ), el estado civil casado ( $p<0,001$ ), el consumo de drogas ( $p$ $<0,01)$ y las ETS previas $(<0,001)$. En el caso del VIH, los predictores fueron la ciudad de residencia $(<0,001)$, el motivo de búsqueda ( $p<0,01)$ y la declaración de una ETS previa ( $p<0,001)$. La población atendida tuvo una mayor prevalencia de sífilis en comparación con el panorama internacional, mientras que los valores de VIH fueron menores. Los predictores asociados a las ITS fueron las mujeres no embarazadas, heterosexuales, con edades comprendidas entre la segunda y la cuarta década de la vida, con estudios superiores y que no utilizaban preservativos regularmente. Este estudio presenta información relevante para la evaluación y desarrollo de medidas de prevención, control y relacionadas con el diagnóstico y tratamiento de las ITS investigadas.

Palabras clave: Epidemiología; Prevalencia; Factores de riesgo; Infecciones de transmisión sexual.

\section{Introduction}

Sexually transmitted infections (STIs) are pathologies that have affected the world population for a long time and constitute a significant collective health problem. Due to the ease of contagion and magnitude of these pathologies, STIs need to be prioritized as public health problems, making it very important to interrupt the transmission chain and prevent new occurrences through basic actions in collective health (Lima, et al., 2003; Ministério da Saúde, 2006).

The World Health Organization (WHO) estimates that around 12 million cases of STIs occur annually in Brazil (World Health Organization, 2001; Aquino, et al., 2008). Under-reporting is still high and close to 200.000 cases per year, especially as a result of the search for alternative treatments. It is estimated that $70 \%$ of affected individuals do not use health services directly, making it difficult to obtain accurate data.

It is estimated that 1 million cases of syphilis occur per year among pregnant women, and early detection and treatment of these women and their partners is advocated, once the infection can be transmitted to the fetus, with serious implications (Ministério da Saúde, 2015; Ministério da Saúde, 2015; Ministério da Saúde, 2015). The elimination of congenital syphilis and vertical HIV transmission has been addressed as a priority in the Latin American and Caribbean regions (Ministério da Saúde, 2015).

The occurrence of STIs in women, especially during pregnancy, increases maternal and fetal risks (Lima \& Viana, 2009). However, the detection of the infection with human immunodeficiency virus (HIV) and syphilis during early pregnancy provides an opportunity for intervention (Inagaki, et al., 2009). Considered as a priority, early detection becomes essential for the adoption of prophylactic measures in the case of pregnant women, such as the use of drugs to reduce the risk of vertical transmission (Volmink, et al., 2002).

In this context, knowledge on regional prevalence and risk factors associated with patients is of paramount importance to improve control measures. It can trigger an epidemiological characterization, and alert for a wide diagnostic screening during the prenatal period, allowing early actions in order to prevent vertical transmission and minimizing the harm to fetal health (Costa, et al., 2010; World Health Organization, 2010). In this study, we investigated the prevalence and predictors 
associated with female patients (pregnant or non-pregnant) with Syphilis and HIV attended at a referrence center in Southern Brazil.

\section{Materials and Methods}

\section{Type, period, and place of study}

This is a cross-sectional, secondary data base study conducted between January and June 2016 with female patients. The database consisted of all patients who sought care in the public service at a referrence center located in the municipality of Paranavaí (latitude: $23^{\circ} 04^{\prime} 23^{\prime \prime}$ S, longitude: 52 $27^{\prime} 55^{\prime \prime} \mathrm{W}$ ), belonging to the 14th Health Regional Agency (RS) of Paraná (PR), Brazil. This Regional Agency attends 28 municipalities, and a population of 259.377 inhabitants.

\section{Variables of interest}

Predictor variables: Gender, age, schooling, marital status, city of origin, pregnant or non-pregnant, number of sexual partners, condom use, STIs carrier in the last year.

Variable outcome: Positive diagnosis for STIs.

\section{Inclusion and exclusion criteria}

Data from female patients (pregnant or not) treated at SINAS between the years of 2013 and 2015 and belonging to one of the municipalities attended by the 14th Regional Health Agency of Paraná were included in this study. The following medical records were excluded: male patients; patients with diseases other than STIs; patients who have acquired the disease before 2013 and after 2015; and patients who did not have the diagnosis determined.

\section{Diagnosis}

All the examinations were performed according to the current norms of the Brazilian Ministry of Health. The tests were performed by trained nurses from the Integrated Health Care System, Paranavaí PR, according to the manufacturers' instructions. For HIV diagnosis, a blood sample was collected using HIV TEST BIOEASY for qualitative detection of antibodies isotypes (IgG, IgM, IgA), specific to HIV-1, including subtype O, and HIV-2, simultaneously in serum, plasma, and whole human blood. For the diagnosis of syphilis, blood samples were collected and analyzed using the immunochromatographic assay (qualitative detection of antibodies of all isotypes, IgG, IgM, IgA) for Treponema pallidum (TP), which detects the presence of syphilis antibodies in the human body, through the immunoassay.

\section{Ethical Aspects}

The study was authorized by SINAS and approved by the Ethics Committee on Research in Human Beings of the State University of Maringá (COPEP/UEM), with registration number 1.375.279 in 12/18/2015. In this work, there was no contact with the patients, and the data were collected directly from the medical records of Integrated Health Care System in Paranavaí.

\section{Typing and Verification of Data Consistency}

The information was entered in the database of the software Epidata $3.1^{\circledR}$, through double typing and Microsoft Excel $^{\mathbb{Q}}$. 


\section{Statistical Analysis}

STATA software version 8.0 (StataCorp LP, College Station, TX) was used for statistical analysis. The descriptive and analytical analysis was performed for all variables, aiming to describe the data collected through the presentation of absolute and percentage values, and to design tables and determine prevalence. The chi-square test was used for bivariate analysis, with statistical significance for values of $p<0.05$. Effect measures such as odds ratios (OR) and $95 \%$ confidence intervals were used to estimate the risk between variables. Then, logistic regression models were developed to identify associations between the predictor variables and the outcome. All variables with a result of $p<0.10$ were included in the final logistic model. After adjustment of the variables, significant associations with values of $\mathrm{p}<0.05$ were considered valid.

\section{Results}

We analyzed data from 6.993 female patients who sought care in the period between January 2013 and December 2015. The general prevalence of STIs was 2.39\% (167/6993). Among the patients attended in the study period, $0.59 \%$ (41/6993) had a positive test for HIV, and 1.80\% (126/6993) were positive for syphilis (Figure 1). The prevalence of positivity during pregnancy was relatively low, for both HIV (0.22\%) (7) and syphilis (0.65\%) (21). Among the 2.674 non-pregnant women, the positivity was $0.78 \%$ (21) for HIV and $3.07 \%$ (82) for syphilis.

Figure 1. Female patients attended at a referral center belonging to the 14th RS- Paraná, Southern Brazil, 2013-2015. Source: Authors.

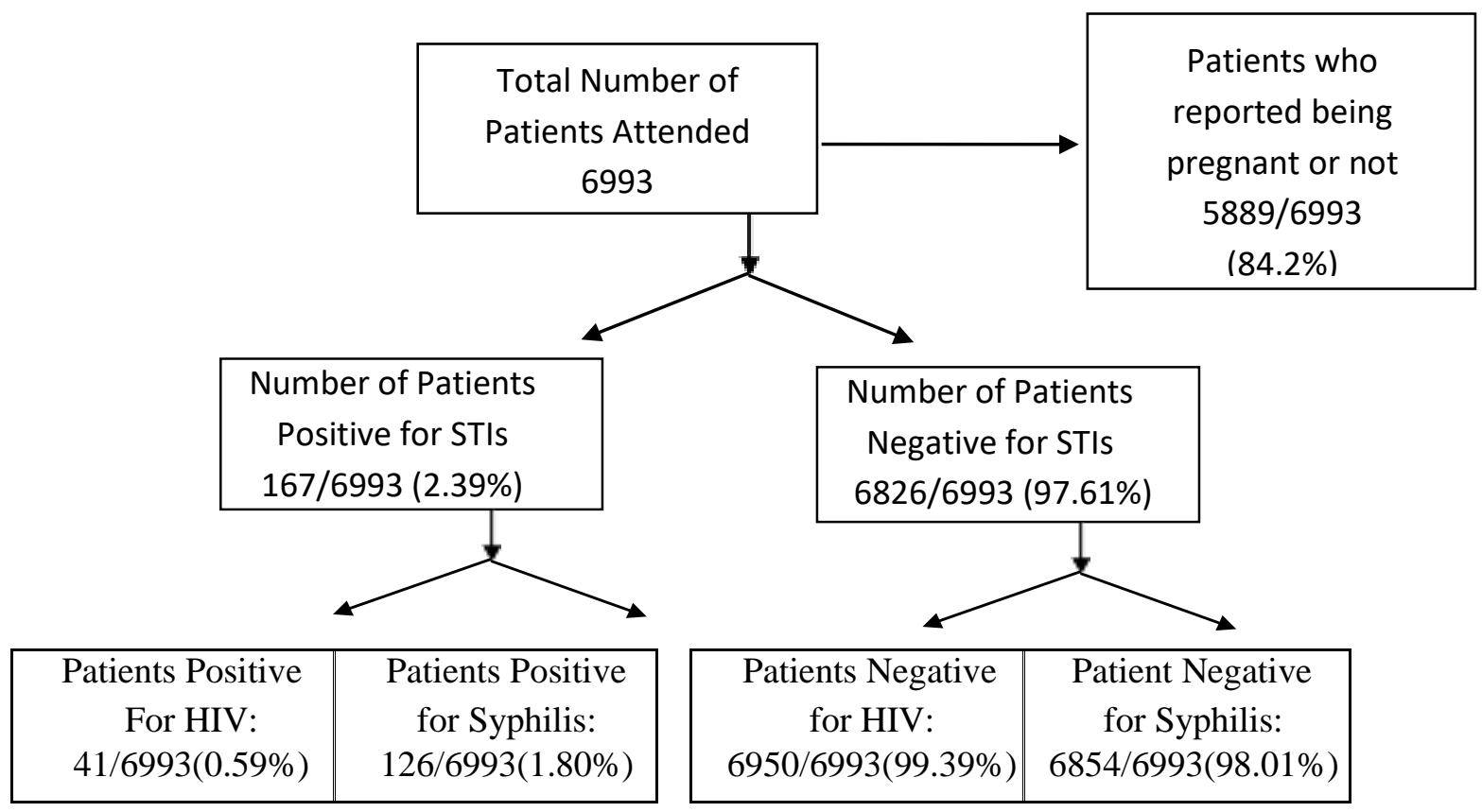

Source: The authors.

Table 1 shows the profile analysis of the women in this study. The predictors' results showed that $59.00 \%$ of the women attended (4.126) were between 21 and 40 years old, 54.59\% (3.215) reported that they were pregnant, 57.57\% (3.975) reported being married, $73.42 \%$ (4.779) had eight or more years of schooling, 95.31\% (6.237) lived in the urban zone, and $32.39 \%$ (2.135) reported using drugs (Table 1). 
Table 1. Socio-demographic characteristics of female patients with STIs attended at a reference center, 14th RS, Paraná, Southern Brazil, 2013-2015.

\begin{tabular}{ll}
\hline Characteristics & $\mathbf{n}(\boldsymbol{\%})$ \\
\hline Age (years) & $1232(17.62)$ \\
$13-20$ & $4126(59.00)$ \\
$21-40$ & $1325(18.95)$ \\
$41-59$ & $310(4.43)$ \\
$60-83$ & \\
Pregnant & $3215(54.59)$ \\
Yes & $2674(45.41)$ \\
No & \\
Marital status & $3975(57.57)$ \\
Married & $2324(33.66)$ \\
Single & $382(5.53)$ \\
Separated & $224(3.24)$ \\
Widow & \\
Schooling & $1805(26.58)$ \\
$<8$ years & $4895(73.42)$ \\
$\geq 8$ years & \\
Zone & $6562(95.31)$ \\
Urban & $323(4.69)$ \\
Rural & \\
City & $6361(91.84)$ \\
Paranavaí & $564(8.16)$ \\
Other Cities & \\
Use of drugs & $2250(32.50)$ \\
Yes & $4674(67.50)$ \\
\hline
\end{tabular}

Source: The authors.

Among the 6.993 women attended, 5.889 reported being pregnant or not, that is 1.104 women chose not to report it. Of those 5.889 women, $54.59 \%$ (3.215/5.889) reported that they were pregnant. Regarding the pregnant women, $45.64 \%$ (3.192/5.889) underwent HIV test and 37.55\% (2.626/5.889) underwent syphilis test. The prevalence of positivity during pregnancy was relatively low, for both HIV (0.22\%) (7) and syphilis (0.65\%) (21). Among the 2.674 non-pregnant women the positivity was $0.78 \%$ (21) for HIV and $3.07 \%$ (82) for syphilis.

Table 2 summarizes the prevalence per year of positive and negative results for HIV and syphilis in the female patients attended. A significant increase in syphilis prevalence $(\mathrm{p}<0.001)$ was observed throughout the years analyzed. The prevalence was $0.40 \%$ in 2013 , increasing to $0.60 \%$ in 2014 , and to $0.80 \%$ in 2015 . On the other hand, HIV positivity showed no statistical association, and varied $0.14 \%$ in 2013 to $0.28 \%$ in 2014 , and $0.18 \%$ in 2015 .

Table 2. Prevalence of positive and negative results in patients attended at a referral center, 14th RS, Paraná, Southern Brazil, 2013-2015.

\begin{tabular}{cccccc}
\hline YEAR & $\begin{array}{c}\text { PATIENTS } \\
\text { ATTENDED n (\%) }\end{array}$ & $\begin{array}{c}\text { POSITIVE HIV } \\
\mathbf{n}(\%)\end{array}$ & $\begin{array}{c}\text { NEGATIVE } \\
\text { HIV } \\
\mathbf{n}(\%)\end{array}$ & $\begin{array}{c}\text { POSITIVE } \\
\text { SYPHILIS* } \\
\mathbf{n}(\%)\end{array}$ & $\begin{array}{c}\text { NEGATIVE } \\
\text { SYPHILIS } \\
\mathbf{n}(\%)\end{array}$ \\
\hline 2013 & $2433(34.79 \%)$ & $10(0.14 \%)$ & $2423(34.65 \%)$ & $28(0.40 \%)$ & $2405(34.39 \%)$ \\
2014 & $3297(47.14 \%)$ & $20(0.28 \%)$ & $3277(46.86 \%)$ & $42(0.60 \%)$ & $3255(46.54 \%)$ \\
2015 & $1263(18.06 \%)$ & $13(0.18 \%)$ & $1250(17.87 \%)$ & $56(0.80 \%)$ & $1194(17.07 \%)$ \\
\hline
\end{tabular}

Note: The values of each year represent individual percentages per disease. The sum due to the positive diagnostic nature for both pathologies provide percentages above $100 \%$. * Statistically significant at $\mathrm{P}<005$. Source: The authors. 
The socio-demographic characteristics of the bivariate of the women studied in the study showed that HIV had an association with the age group 21-40 years old (OR 0.2; $\mathrm{p}=0.016$ ), while syphilis had an association with the age groups 21-40 years old (OR 2.2; p<0.01), 41-59 years old (OR 5.5; p<0.001) and 60-83 years old (OR 12.3; p<0.001) (Table 3).

The prevalence of HIV and syphilis was higher in non-pregnant women, with 75\%, (OR 3.9; p <0.001) for HIV, and 79.61\% for syphilis (OR 5.4; p <0.001). Women with married marital status had a high positivity rate for syphilis (OR 3.0; $\mathrm{p}<0.01)$ when compared to the separated marital status. The level of schooling $\geq 8$ years had higher positivity for HIV (OR 2.8; $\mathrm{p}<0.01)$ and syphilis (OR 2.6; $\mathrm{p}<0.001)$ in this study. The lowest prevalence for HIV occurred in the city of Paranavaí (OR 0.1; $\mathrm{p}<0.001$ ). Patients using any type of drug had higher positivity for syphilis $53.23 \%$ (OR 2.4; p<0.001) when compared with those who reported no use (Table 3).

Table 3. Socio-demographic characteristics of women with HIV and Syphilis attended at an Integrated Health Care Center, South of Brazil.

\begin{tabular}{ll}
\hline Predictor & HIV*
\end{tabular}

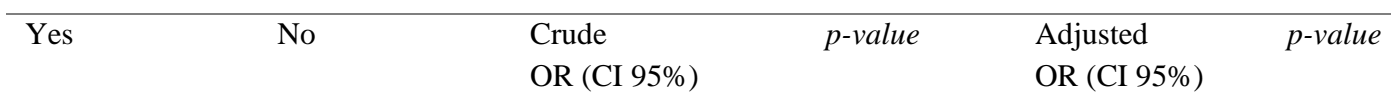

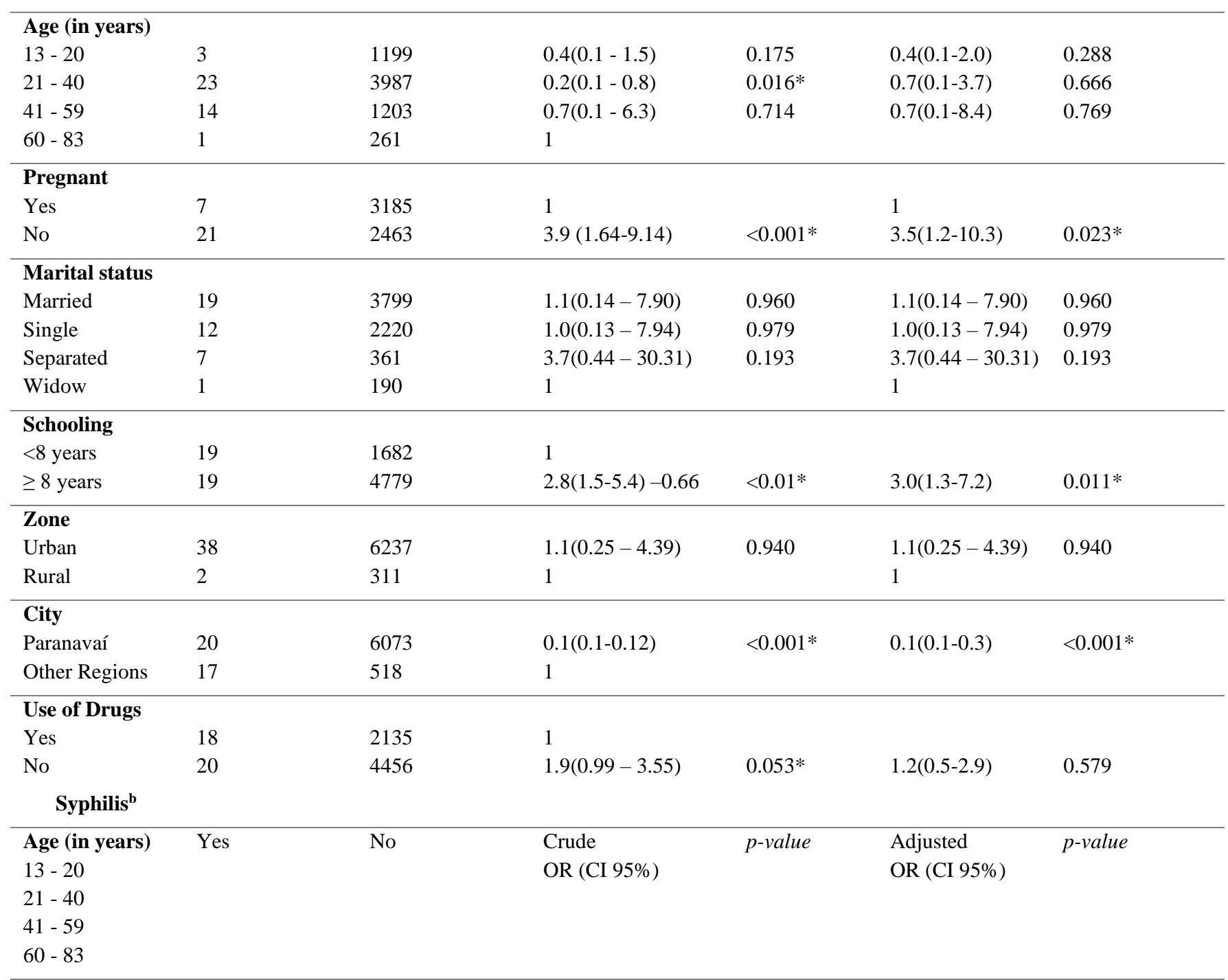

\section{Marital status}

Married

21

2605

1 


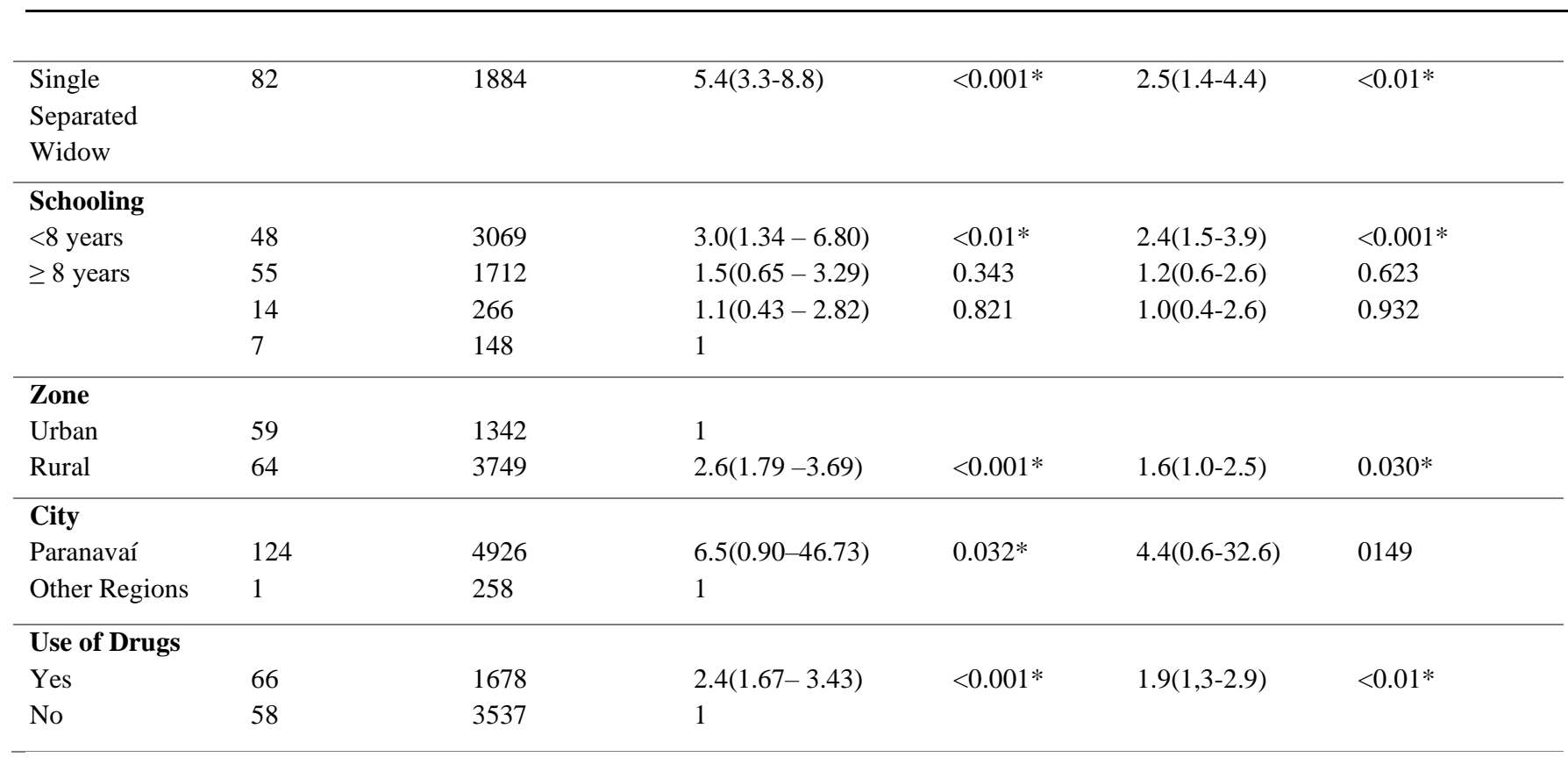

${ }^{\mathrm{a}}$ Adjusted for por age, marital status, and zone. $\mathrm{OR}=$ odds ratio; $\mathrm{CI}=$ confidence interval. ${ }^{\mathrm{b}}$ Adjusted by Zone. *Statistically significant at $\mathrm{P}<$ 005. The values with unit zero, could not be included in the logistic regression. Source: The authors.

The predictor of reason for searching examinations showed that for HIV there was growth in the risk gradients prevention (OR 2.7; $\mathrm{p}=0.018$ ), medical request (OR 4.2; $\mathrm{p}<0.01$ ) and other health services (OR 14.8; $\mathrm{p}<0.001)$. For syphilis, the estimated risk rates were prevention (OR 3.1; $<<0.001)$, medical request (OR 4.7; $\mathrm{p}<0.001)$, and other health services (OR 3.7; $\mathrm{p}<0.01$ ) (Table 4).

Patients who reported having developed any type of STIs previously had positive results in this study, both for HIV (OR 11.7; $\mathrm{p}<0.001$ ) and syphilis (OR 4.7; $\mathrm{p}<0.001$ ). Considering types of sexual partners, the results showed a higher risk for women who had a relationship with men and women (OR 7.5; $\mathrm{p}<0.01$ ) when compared to women who had a relationship with women only. The lack of condom during sexual intercourse showed a higher positivity for the HIV virus, 47.22\% (OR 4.4; $\mathrm{p}<0.01)$, while condom use reported as "sometimes" showed significant results for both HIV $33.33 \%$ (OR 3.8; $<<0.01)$ and syphilis $20.72 \%$ (OR 3.5; p <0.01) (Table 4).

Table 4. Clinical-epidemiological characteristics of women with HIV and Syphilis attended at an Integrated Health Care Center, South of Brazil.

\begin{tabular}{|c|c|c|c|c|c|c|c|c|c|c|c|c|}
\hline \multirow[t]{2}{*}{ Predictor } & \multicolumn{5}{|c|}{ HIV $^{\mathbf{a}}$} & \multicolumn{7}{|c|}{ Syphilis $^{\mathbf{b}}$} \\
\hline & Yes & No & $\begin{array}{l}\text { Crude } \\
\text { OR }(95 \% \text { IC) }\end{array}$ & p-value & $\begin{array}{l}\text { Adjusted } \\
\text { OR (95\% IC) }\end{array}$ & p-value & Yes & No & $\begin{array}{l}\text { Crude } \\
\text { OR (95\% IC) }\end{array}$ & $p$-value & $\begin{array}{l}\text { Adjusted } \\
\text { OR (95\% IC) }\end{array}$ & $p$-value \\
\hline \multicolumn{13}{|l|}{ Gestational Age } \\
\hline 1st Trimester & 5 & 1510 & $2.6(0.3-21.9)$ & 0.391 & $2.6(0.3-21.9)$ & 0.391 & 11 & 1274 & $1.2(0.50-3.0)$ & 0.742 & $1.2(0.50-3.0)$ & 0.742 \\
\hline 2nd Trimester & 0 & 881 & - & & - & & 7 & 691 & $1.8(0.6-6.5)$ & 0.369 & $1.8(0.6-6.5)$ & 0.369 \\
\hline 3rd Trimester & 1 & 773 & 1 & & 1 & & 3 & 625 & 1 & & 1 & \\
\hline \multicolumn{13}{|l|}{ Seek Reason } \\
\hline Prevention & 8 & 1313 & $2.7(1.2-6.2)$ & 0.018 & $2.7(1.0-6.9)$ & $0.044 *$ & 30 & 1086 & $3.1(1.8-5.4)$ & $<0.001^{*}$ & $1.3(.06-3.1)$ & 0.531 \\
\hline Pre-Natal Examination & 5 & 2889 & 1 & & & & 21 & 2353 & 1 & & & \\
\hline Medical request & 20 & 2135 & $4.2(1.6-11.3)$ & $<0.01$ & $4.6(1.5-14.7)$ & $<0.01^{*}$ & 67 & 1582 & $4.7(2.9-7.8)$ & $<0.001 *$ & $2.8(1.1-7.1)$ & $0.029 *$ \\
\hline Other health services & 8 & 313 & $14.8(4.8-45.4)$ & $<0.001$ & $13.4(3.7-48.4)$ & $<0.001^{*}$ & 8 & 243 & $3.7(1.6-8.4)$ & $<0.01 *$ & $1.0(0.4-2.6)$ & 0.923 \\
\hline \multicolumn{13}{|l|}{ Blood donor } \\
\hline Yes & 3 & 388 & $1.3(0.4-4.3)$ & 0.637 & $1.3(0.4-4.3)$ & 0.637 & 6 & 316 & $1.3(0.6-2.9)$ & 0.558 & $1.3(0.6-2.9)$ & 0.558 \\
\hline No & 36 & 6188 & 1 & & 1 & & 119 & 4892 & 1 & & 1 & \\
\hline \multicolumn{13}{|l|}{ Had STI } \\
\hline Yes & 14 & 354 & $11.7(0.04-0.17)$ & $<0.001 *$ & 7.9(3.8-16.4) & $<0.001^{*}$ & 26 & 285 & $4.7(3.0-7.4)$ & $<0.001 *$ & $3.9(2.5-6.4)$ & $<0.001 *$ \\
\hline No & 21 & 6199 & 1 & & & & 95 & 4900 & 1 & & & \\
\hline
\end{tabular}




\begin{tabular}{|c|c|c|c|c|c|c|c|c|c|c|c|c|}
\hline \multicolumn{13}{|l|}{ Types of sexual partners } \\
\hline Men and Women & 0 & 16 & - & - & - & - & 2 & 12 & $7.5(1.7-33.9)$ & $<0.01 *$ & $6.2(1.3-29.1)$ & $0.020 *$ \\
\hline Men & 38 & 6118 & - & - & - & - & 108 & 4861 & $1.3(0.2-9.2)$ & 0.816 & $1.3(0.2-9.7)$ & 0.792 \\
\hline \multirow[t]{2}{*}{ Women } & 0 & 69 & - & - & - & - & 1 & 57 & 1 & & & \\
\hline & & & & & & & & $(1.16)$ & & & & \\
\hline Type of Exposure & & & & - & & & & & & & & \\
\hline More than one Exposure & 0 & 26 & - & & & & 1 & 20 & $0.1(0.1-8.1)$ & 0.983 & $0.1(0.1-8.1)$ & 0.983 \\
\hline Sexual Intercourse & 37 & 5964 & - & - & - & - & 109 & 4723 & $0.4(0.1-3.5)$ & 0.453 & $0.4(0.1-3.5)$ & 0.453 \\
\hline Exposure to Biol Mat & 0 & 55 & - & - & & & 0 & 40 & - & & - & \\
\hline Vertical Transmission & & & & & & & 0 & 9 & - & & - & \\
\hline Does not report Risk & 0 & 10 & - & - & - & - & 9 & 176 & $0.1(0.0-2.3)$ & 0.149 & $0.1(0.0-2.3)$ & 0.149 \\
\hline \multirow[t]{2}{*}{ Other types } & 0 & 223 & - & - & - & - & 1 & 2 & 1 & & 1 & \\
\hline & & & - & & & & & & & & & \\
\hline \multicolumn{13}{|l|}{ Condom use } \\
\hline Every time & 7 & 336 & 1 & & & & 12 & 263 & 1 & & & \\
\hline Did not use & 17 & 3656 & $4.4(1.8-10.9)$ & $<0.01 *$ & $3.3(1.3-8.7)$ & $0.016^{*}$ & 76 & 2867 & $1.7(0.9-3.2)$ & 0.083 & $1.2(0.6-2.2)$ & 0.677 \\
\hline Used sometimes & 12 & 2169 & $3.8(1.5-9.6)$ & $<0.01 *$ & $2.1(0.8-5.9)$ & 0.143 & 23 & 1765 & $3.5(1.7-7.1)$ & $<0.01 *$ & $2.2(1.0-4.7)$ & $0.037 *$ \\
\hline
\end{tabular}

${ }^{\mathrm{a}}$ Adjusted for gestational age and blood donor. ${ }^{\mathrm{b}}$ Adjusted by gestational age, blood donor and type of exposure. OR $=$ odds ratio; $\mathrm{CI}=$ confidence interval.

${ }^{b}$ Adjusted by Zone. *Statistically significant at $\mathrm{P}<005$. The values with unit zero, could not be included in the logistic regression. Source: The authors.

Multiple logistic regression analysis was conducted to define the impact of different predictors of HIV and syphilis diseases. We can highlight that patient in the age groups of 21-40 (OR 2.5, p = 0.031), 41-59 (OR 5.2, p <0.001) and 60-83 (OR 11.3; p <0.001) years old showed higher prevalence of syphilis. Non-pregnant women were more likely to be positive for the diseases in this study (HIV (OR 3.5, p = 0.023) and syphilis (OR 2.5, p <0.01)). Women with married marital status had a larger positivity rate for syphilis (OR 2.4; $\mathrm{p}<0.001)$ when compared to the separated marital status (Table 3).

The level of schooling $\geq 8$ years had higher positivity for HIV (OR 3.0; $\mathrm{p}=0.011)$ and syphilis $(\mathrm{OR} 1.6 ; \mathrm{p}=0.030)$ in this study. For the predictor city, patients living in Paranavaí showed a greater significant prevalence of HIV (OR 0.1; p $<0.001)$. Regarding drug use, women who reported having used some types of drugs were more likely to have syphilis (OR $1.9, \mathrm{p}<0.01)($ Table 3).

The adjusted variables still yielded other relevant results. The predictor seek reason for examinations showed that for HIV risk gradients, prevention (OR 2.7; $\mathrm{p}=0.044)$, medical request $(\mathrm{OR} 4.6 ; \mathrm{p}<0.01)$ e other health services $(\mathrm{OR} 13.4$; $\mathrm{p}<0.001)$ grew. For syphilis, the estimated risk rates were for medical request (OR 2.8; p<0.001). Patients who had other STIs showed strong association with the presence of HIV (OR 7.9; p<0.001) and syphilis (OR 3.9; p<0.001) with patients in this study (Table 4). Type of sexual partner with adjusted analysis values showed that women who have a relationship with women and men had a higher risk of syphilis positivity (OR 6.2; p =0.020), while the analysis of condom use brought greater positivity for those who did not use any type (OR 3.3; $\mathrm{p}=0.016)$ for HIV and used sometimes $(\mathrm{OR} 2.2 ; \mathrm{p}=0.037)$ for syphilis (Table 4).

\section{Discussion}

The World Health Organization (WHO) estimated that in 2012, there were 357 million new STIs cases, with an international prevalence of STIs of around 4.5\% worldwide (Torrone, et al., 2018). It is estimated that 1.8 million people were infected with HIV in 2016. Syphilis affects HIV (OR 3.5, p = 0.023) and syphilis (OR 2.5, p <0.01). Many studies have found similar and other rates (Newman, et al., 2015; World Health Organization, 2016; Gomes, et al., 2017; Dionne-Odom, et al., 2018; Bennani, et al., 2017; Olugbenga, et al., 2018; Saindou, et al., 2012; Ginindza, et al., 2017) varying according to the region and type of study. In Latin America and the Caribbean, it is estimated that between 166.000 and 344.000 children are born with congenital syphilis annually (Ministério da Saúde, 2006; World Health Organization, 2001; Aquino, et al., 2008; Ministério da Saúde 2015). In our study the prevalence of STIs was of $2.39 \%$. 
The prevalence of syphilis observed in this study in non-pregnant women was of $3.07 \%$, which is close to the $4.3 \%$ prevalence in women found by Gomes et al. (2017) in a study with Brazilian data. Other publications have demonstrated oscillating values, with lower prevalence rates. Dionne-Odom et al. (2018) described the prevalence of $1.6 \%$ of women infected with HIV and Syphilis in the South of the United States, while Bennani et al. estimated lower prevalence in Morocco (0.56\%) (Bennani, et al., 2017).

The HIV prevalence in women reported in this study was $0.78 \%$. A study with HIV positive women in Nigeria also reported low prevalence (3\%) (Olugbenga, et al., 2018), and in a study in the Indian Ocean, no prevalent case of HIV infection was detected (Saindou, et al., 2012). However, among women of reproductive age in Swaziland, the prevalence was 42.7\%, according to Ginindza, et al., (2017). Different prevalence rates among countries with different socio-demographic characteristics is consistent in research of this nature, and they may also reflect, partly, the effect of syndromic STIs treatment performed by health services over the years (Yahya-Malima, et al., 20018).

In multivariate analysis of risk factors for predictors, data demonstrated an increasing risk gradient according to age. The age group 21-40 years old had an estimated risk for syphilis more than twice the risk for the age 13-20, while for the age groups 41-59 and 60-83 years old the risk was approximately five times and eleven times, respectively, higher than the group 13-20. The prevalence of positivity was also concentrated in the age group 20-34 years in the studies by Oliveira et al. (2014) (20-34 years) and Gomes et al. (2017), with a higher positivity in the age group of 25-34 years.

Pregnancy is a phase in which women need medical follow-up (prenatal examinations), and this monitoring becomes a protection for them. After modeling the adjusted variables of this study, the data analyzed evidenced that the predictor nonpregnant had a significant prevalence when associated to the presence of HIV and syphilis, with a higher risk for syphilis $(\mathrm{OR}=2.5 ; \mathrm{p}<0.01)$ compared to HIV $(\mathrm{OR}=3.5 ; \mathrm{p}<0.023)$.

Syphilis had an increasing tendency during the period from 2013 to 2015, while for HIV the relevant increase was from 2013 to 2015 . Regarding the year 2015, we believe that one of the reasons for the small number of cases is underregistration in the system. This is a problem presented with some frequency by secondary databases, and it is the absence or sub-registration of data, which hinders the integrity of the analyses (Scheidell, et al., 2018). Patients with married marital status had a higher prevalence of positivity for HIV (48.7\%) and syphilis (38.71\%), and married patients with positivity for syphilis had twice the risk when compared to patients with widow marital status.

Few studies are available involving the detection of STIs in women, comparing pregnant or non-pregnant women (Costa, et al., 2010; Oliveira, et al., 2014; Scheidell, et al., 2018). It is important to highlight that the studies used to compare our findings belonged to similar referrence centers. Early diagnosis, combined with knowledge of the physical and social characteristics of the affected population, such as their lifestyle, age, gender, profession, among others, has been highly effective in preventing new cases through educational measures for the specific population, thus preventing the development of severe cases that evolve to malignancy and death (Miranda, et al., 2018; Conceição, et al., 2009; Liell, et al., 2009). Many aspects regarding the pathology and impact of STIs infections in public health are still poorly known, evidencing the importance of studies directed to epidemiology (World Health Organization, 2001).

\section{Conclusion}

In conclusion, a significant frequency of syphilis infection was demonstrated in women attending the Integrated Health Care System in southern Brazil. The syphilis infection showed a significant association with the predictors older than 45 years, non-pregnant, married marital status, use of drugs, and reported previous STI. For HIV the predictors were city of residence, seek reason, and previous STI reported. Epidemiological studies can help in the implementation of adequate practices for the prevention and detection of infected women, as well as reduce the spread of the infection in the community. 
Also, it is important to highlight that this type of study contributes to improve the quality of life, and to reduce public health costs.

\section{Acknowledgements}

The State University of Maringá and Integrated Health Care System (SINAS).

\section{Conflict of interest}

The authors of this paper declare that they have no conflict of interest.

\section{Funding}

This research did not receive any specific grant from funding agencies in the public, commercial, or not-for-profit sectors.

\section{References}

Aquino, P. S., Nicolau, A. I. O., Moura, E. R. F., Pinheiro, A. K. B. (2008). Perfil sociodemográfico e comportamento sexual de prostitutas de Fortaleza - CE. Texto Contexto Enferm, 17 (3), 427-34.

Bennani, A., ElKettani, A., HancËali, A., ElRhilani, H., Alami, K., Youbi, M., et al. (2017). The prevalence and incidence of active syphilis in women in Morocco, 1995-2016: Model-based estimation and implications for STI surveillance. PLoS ONE, 12 (8), e0181498.

Brocklehurst, P., Volmink, J. (2002). Antiretrovirals for reducing the risk of mother-to-child transmission of HIV infection. Cochrane Database Syst Rev., (1), CD003510.

Conceição, J. S., Diniz-Santos, D. R., Ferreira, C. D., Paes, F. N., Melo, C. N., Silva, L. R. (2009). Conhecimento dos obstetras sobre a transmissão vertical da hepatite B. Arq Gastroenterol, 46 (1), 57-61.

Costa, M. C., Bornhausen-Demarch, E., Azulay, D. R., Périssé, A. R. S., Dias, M. F. R. G., Nery, J. A. C. (2010). Sexually transmitted diseases during pregnancy: a synthesis of particularities. An Bras Dermatol., 85 (6), 767-85.

Dionne-Odom, J., Westfall, A. O., Van, Der. Pol, B., Fry, K., Marrazzo, J. (2018). Sexually Transmitted Infection Prevalence in Women with HIV: Is There a Role for Targeted Screening? Sexually Transmitted Diseases, 45 (11), 762-769.

Ginindza, T. G., Stefan, C. D., Tsoka-Gwegweni, J. M., Dlamini, X., Jolly, P. R., Weiderpass, E., Broutet, N., Sartorius, B. (2017). Prevalence and risk factors associated with sexually transmitted infections (STIs) among women of reproductive age in Swaziland. Infectious Agents and Cancer, 12 (29).

Gomes, N. C. R. C., Meier, D. A. P., Pieri, F. M., Alves, E., Albanese, S. P. R., Lentine, E. C., Arcêncio, R. A., Dessunti, E. M. (2017). Prevalence and factors associated with syphilis in a Reference Center. Rev Soc Bras Med Trop., 50 (1), 27-34.

Inagaki, A. D. M., Oliveira, L. A. R., Oliveira, M. F. B., Santos, R. C. S., Araújo, R. M., Alves, J. A. B. et al (2009). Soroprevalência de anticorpos para toxoplasmose, rubéola, citomegalovírus, sífilis e HIV em gestantes sergipanas. Rev Soc Bras Med Trop., 42 (5), 532-6.

Liell, A. P., Weber, D., Toscan, C., Fornari, F., Madalosso, L. F. (2009). Prevalência do HBSAg em gestantes de Passo Fundo, RS: estudo comparativo entre os sistemas de saúde público e privado. Arq Gastroenterol., 46 (1), 75-7.

Lima, G. R., Girão, M. J. B. C., Baracat, E. C. (2003). Doenças Sexualmente Transmissiveis. In: Ginecologia de Consultório, Editora de Projetos Médicos. São Paulo-SP, 193-210.

Lima, L. H. M., Viana, M. C. (2009). Prevalence and risk factors for HIV, syphilis, hepatitis B, hepatitis C, and HTLV-I/II infection in low-income postpartum and pregnant women in Greater Metropolitan Vitória, Espírito Santo State, Brazil. Cad Saude Publica, 25 (3), 668-76.

Ministério da Saúde- Brasil. Secretaria de Vigilância em Saúde. Programa Nacional de DST e Aids. Manual de bolso das doenças sexualmente transmissíveis. Brasília (DF) 2006; 111 p.

Ministério da Saúde- Brasil. Secretaria de Vigilância em Saúde. Departamento de DST, AIDS e Hepatites Virais. Boletim Epidemiológico. 2015; Hepatites Virais. Ano IV- $\mathrm{n}^{\mathrm{o}} 1$.

Ministério da Saúde- Brasil. Secretaria de Vigilância em Saúde. Departamento de DST, AIDS e Hepatites Virais. Boletim Epidemiológico. 2015; HIV. Ano IV- $\mathrm{n}^{\mathrm{o}} 1$.

Ministério da Saúde- Brasil. Secretaria de Vigilância em Saúde. Departamento de DST, AIDS e Hepatites Virais. Boletim Epidemiológico. 2015; Sífilis. Ano IV.

Miranda, A. E., Figueiredo, N. C., Pinto, V. M., Page, K., Talhari, S. (2012). Risk factors for syphilis in young women attending a family health programme in Vitoria, Brazil. An Bras Dermatol., 87 (1), 76-83. 
Research, Society and Development, v. 10, n. 13, e134101320989, 2021

(CC BY 4.0) | ISSN 2525-3409 | DOI: http://dx.doi.org/10.33448/rsd-v10i13.20989

Newman, L., Rowley, J., Vander Hoorn, S., Wijesooriya, N. S., Unemo, M., Low, N., et al (2015). Global estimates of the prevalence and incidence of four curable sexually transmitted infections in 2012 based on systematic review and global reporting. PLOS ONE, 10 (12), e0143304.

Oliveira, L. R., Costa, M. C. N., Barreto, F. R., Pereira, S. M., Dourado, I., Teixeira, M. G. (2014). Evaluation of preventative and control measures for congenital syphilis in State of Mato Grosso. Rev Soc Bras Trop., 47 (3), 334-340.

Olugbenga, I., Taiwo, O., Laverty, M., Ngige, E., Anyaike, C., Bakare, R., et al (2018). Clinic-based evaluation study of the diagnostic accuracy of a dual rapid test for the screening of HIV and syphilis in pregnant women in Nigeria. PLoS ONE, 13 (7), e0198698.

Saindou, M., Bénet, T., Troalen, D., Abaine, A., Voirin, N., Giard, M., Vanhems, P. (2012). Prevalence and risk factors for HIV, hepatitis B virus, and syphilis among pregnant women in Mayotte, Indian Ocean, 2008-2009. Int J Gynaecol Obstet., 119 (1), 61-5.

Scheidell, J. D., Beau, De Rochars, V. M., Séraphin, M. N., Hobbs, M. M., Morris, J. G. Jr., Célestin, J. P., Cottler, L. B., Khan, M. R. (2018). Socioeconomic Vulnerability and Sexually Transmitted Infection among Pregnant Haitian Women. Sex Transm Dis., 45 (9), 626-631.

Torrone, E. A., Morrison, C. S., Chen, P-L., Kwok, C., Francis, S. C., Hayes, R. J., et al (2018). Prevalence of sexually transmitted infections and bacterial vaginosis among women in sub-Saharan Africa: An individual participant data meta-analysis of 18 HIV prevention studies. PLoS Med., 15 (2), e1002511.

World Health Organization. Department of HIV/AIDS. Global prevalence and incidence of selected curable sexually transmitted infections, 2001.

World Health Organization. Global health sector strategy on sexually transmitted infections 2016-2021: towards ending STIs. Geneva: World Health Organization, 2016.

World Health Organization. UNAIDS- AIDS Epidemic Update, 2010.

Yahya-Malima, K. I., Evjen-Olsen, B., Matee, M. I., Fylkesnes, K., Haarr, L. (2008). HIV-1, HSV-2 and syphilis among pregnant women in a rural area of Tanzania: prevalence and risk factors. BMC Infect Dis., 8 (75). 